\title{
Surgical quality: review of Californian measures
}

\author{
Michael S Broder, Lisa Payne Simon, Robert H Brook
}

Zynx Health, Beverly Hills, CA 90212, USA

Michael S Broder vice president

RAND Health, Santa Monica, CA Robert H Brook director

California

HealthCare

Foundation,

San Francisco, CA

Lisa Payne Simon senior program officer

Correspondence to:

M S Broder

mbroder@

cerner.com

BMJ 2004;328:152-3
Many countries publicly report data on the quality of health care. Because surgical patients often have time to plan their care they are ideal candidates to use such data. We examined the adequacy of publicly reported data about surgical quality in California. We used data specific to California because this state is the most populous in the United States and more surgery is done here than in any other state. We defined surgical procedures as those invasive procedures listed by the National Center for Health Statistics.

\section{Methods and results}

We updated a list of organisations that reported on quality in California in 1998 by telephoning those organisations and searching the internet for new sources of data about quality. We surveyed all organisations and collected data about publicly reported quality

Measures of surgical quality, California, 1999

\begin{tabular}{|c|c|c|c|c|}
\hline Procedure & Measure & $\begin{array}{l}\text { Risk adjustment } \\
\text { method }\end{array}$ & $\begin{array}{l}\text { Volume of } \\
\text { procedures } \\
\text { (No covered) }\end{array}$ & $\begin{array}{c}\text { Percentage of } \\
\text { all invasive } \\
\text { procedures } \\
(\mathrm{n}=2381601)\end{array}$ \\
\hline \multicolumn{5}{|l|}{ Healthcare structure } \\
\hline $\begin{array}{l}\text { Abdominal aortic } \\
\text { aneurysm resection or } \\
\text { replacement }\end{array}$ & Annual hospital volume & None & 3120 & 0.13 \\
\hline Coronary bypass & Annual hospital volume & None & 56130 & 2.36 \\
\hline Carotid endarterectomy & Annual hospital volume & None & 12340 & 0.52 \\
\hline $\begin{array}{l}\text { Oesophageal cancer } \\
\text { surgery }\end{array}$ & Annual hospital volume & None & 421 & 0.02 \\
\hline $\begin{array}{l}\text { Solid organ transplant } \\
\text { (8 types) }\end{array}$ & Annual hospital volume & None & 2586 & 0.11 \\
\hline Total & & & $\begin{array}{c}74597 \\
\text { (12 procedures) }\end{array}$ & 3.13 \\
\hline Healthcare process & None & - & 0 & 0 \\
\hline \multicolumn{5}{|l|}{ Healthcare outcome } \\
\hline Coronary bypass & Death rate & $\begin{array}{l}\text { Medical record } \\
\text { abstraction }\end{array}$ & 56130 & 2.36 \\
\hline $\begin{array}{l}\text { Solid organ transplant } \\
\text { (8 types) }\end{array}$ & Death rate & $\begin{array}{l}\text { Medical record } \\
\text { abstraction }\end{array}$ & 2586 & 0.11 \\
\hline $\begin{array}{l}\text { Percutaneous } \\
\text { transluminal coronary } \\
\text { angioplasty }\end{array}$ & Combined rate $^{*}$ & Administrative data & 94051 & 3.95 \\
\hline Spinal fusion & Combined rate* & Administrative data & 16314 & 0.69 \\
\hline $\begin{array}{l}\text { Back and neck surgery } \\
\text { (other than fusion) }\end{array}$ & Combined rate $^{*}$ & Administrative data & 27840 & 1.17 \\
\hline Coronary bypass & Combined rate $^{*}$ & Administrative data & 56130 & 2.36 \\
\hline $\begin{array}{l}\text { Knee replacement } \\
\text { (primary) }\end{array}$ & Combined rate $^{*}$ & Administrative data & 22452 & 0.34 \\
\hline Hip replacement (primary) & Combined rate $^{*}$ & Administrative data & 15247 & 0.64 \\
\hline Prostatectomy & Combined rate $^{*}$ & Administrative data & 20390 & 0.86 \\
\hline $\begin{array}{l}\text { Peripheral vascular } \\
\text { interventional } \\
\text { procedures }\end{array}$ & Combined rate $^{*}$ & Administrative data & 5294 & 0.22 \\
\hline $\begin{array}{l}\text { Peripheral vascular } \\
\text { bypass and revision }\end{array}$ & Combined rate $^{*}$ & Administrative data & 6971 & 0.29 \\
\hline Valve replacement & Combined rate $^{*}$ & Administrative data & 8408 & 0.35 \\
\hline $\begin{array}{l}\text { Abdominal aortic } \\
\text { aneurysm resection or } \\
\text { replacement }\end{array}$ & Combined rate $^{\star}$ & Administrative data & 3120 & 0.13 \\
\hline Total & & & $\begin{array}{c}270395 \\
\text { (19 procedures) }\end{array}$ & 11.59 \\
\hline Total all measures & & & $291564 \dagger$ & $12.00 \dagger$ \\
\hline
\end{tabular}

${ }^{*}$ Combined death in hospital and complication rate

tSome procedures have more than one quality measure. measures including procedures covered, risk adjustment method, and new measures planned for release by 2005 .

We found 18 organisations that reported 333 measures of healthcare quality. All measures examined quality at the hospital level; none related to quality of individual surgeons, groups of surgeons, or health plans. A total of 32 measures (10\%) rated quality for 21 procedures. These 21 procedures accounted for 270395 $(12 \%)$ of the 2381601 surgical procedures performed in California in 1999 (table). ${ }^{2}$ The organisations reported structure, process, and outcome measures on 12,0 , and 19 procedures. Several procedures had more than one reported outcome measure. Six of the 10 most common non-obstetric procedures had none (coronary artery stent placement, hysterectomy, cholecystectomy, open reduction or internal fixation of fracture, oophorectomy, and appendectomy). The most often reported outcome was death in hospital and major complication rate, which was reported for 11 different procedures. These procedures comprise $11.6 \%$ of the Californian total.

Except for hospital volume, all measures were risk adjusted. For all measures except death rates for solid organ transplants and coronary artery bypass grafting, risk adjustment relied on routinely collected administrative data, using ICD-9-CM (international classification of diseases, 9th revision, clinical modification) discharge codes.

The time lag between collecting data and reporting varied between six and 36 months. Measures other than annual volumes are based on reporting periods of two to three years. As a result, most current measures reflected care delivered between two and five years ago. Except for coronary artery bypass surgery and transplants, all measures relied on data reported under statutory requirements (for example, hospitals receiving Medicare payments must report deaths and complications).

Three new measures are expected by 2005 (related to hip fracture, carotid endarterectomy, and coronary artery bypass grafting). In California by 2005, public reporting of mortality risk adjusted for coronary artery bypass grafting will become mandatory and will include deaths specific to individual surgeons.

\section{Comment}

We found few data to help a consumer interested in using quality to select a surgeon or hospital, and the existing data had serious shortcomings. We found no data specific to surgeons, that most outcome measures used administrative risk adjustment, and no reporting of process measures or functional assessments-for example, walking after hip replacement. Most common procedures had no associated quality measures at all. For some complex procedures, researchers have found an inverse association between volume (a commonly reported measure) and mortality. ${ }^{3}$ However, this association may not hold for most surgeries. ${ }^{4}$ For common surgical procedures, selecting a high volume 
hospital may not improve outcomes. Only three new measures are expected over the next three years.

For $88 \%$ of surgical patients in California, no publicly reported information exists. These patients must rely on indirect measures, such as academic affiliation, to assess quality. Even consumers who have conditions for which data are reported face difficulties in using these limited data.

Without a new major effort to increase both the number of procedures for which quality measures are available and the validity of those measures, most California consumers will not be able to choose surgical providers based on quality. A competitive market cannot exist under these conditions.

Contributors: MSB collected, analysed, and interpreted the data. $\mathrm{RHB}$ had the concept, interpreted the data, and wrote the manuscript. LPS had the concept, collected data, and wrote the manuscript. MSB is guarantor.

Funding: This work was supported in part by a grant from the California HealthCare Foundation and by the UCLA Building Interdisciplinary Research Careers in Women's Health Program.

Competing interests: None declared.

Ethical approval: Not needed.

1 Gillum BS, Graves EJ, Jean L. Trends in hospital utilization: united states, 1988-92. Vital Health Stat 13 1996;(124):1-71.

2 Office of Statewide Health Planning and Development. Hospital annual utilization. www.oshpd.state.ca.us/hqad/HIRC/hospital/util/pivot/ index.htm. (accessed 7 Jan 2003).

3 Epstein AM. Volume and outcome: it is time to move ahead. N Engl J Med 2002;346:1161-4.

4 Khuri SF, Daley J, Henderson W, Hur K, Hossain M, Soybel D, et al. Relation of surgical volume to outcome in eight common operations: results from the VA national surgical quality improvement program. Ann Surg 1999;230:414-32.

(Accepted 22 October 2003)

\title{
Commentary: Not everything that counts can be counted; not everything that can be counted counts
}

\author{
Martin McKee
}

Few examples better show the triumph of ideology over evidence than the continuing quest to encourage patient choice by publishing the outcomes of healthcare providers. ${ }^{1}$ Perhaps because the stated objectives seem so self evidently reasonable-providing information to the public who pay for and use health services and supporting patients' ability to choose where they will be treated-opposition to this idea from sceptics is difficult without being accused of paternalism or worse. But the task of improving health care by publishing outcomes is far from simple. ${ }^{2-4}$ Essentially there are at least three problems. The first is to develop a means of assessing outcomes that provides comparable information which allows patients reliably to differentiate good and bad performers, adequately capturing differences in case mix and with sufficient power that differences do not arise by chance. ${ }^{5}$ The second is to embed this information within a system that leads to genuine improvements in quality by those underperforming, rather than opportunistic behaviour in relation to either recording ${ }^{6}$ or work undertaken, ${ }^{7}$ designed solely to improve what is reported which often makes things worse. The culture of often meaningless targets within the NHS is throwing up new examples of the latter almost every week. The most recent is the way in which hospital emergency departments, anxious not to exceed the target for patients to wait no longer than four hours before being admitted or discharged, are now refusing to admit patients from waiting ambulances until they are ready to be seen. Ambulance trusts, whose vehicles are tied up in queues outside hospitals, are investing in inflatable tents into which their patients can be deposited, in a kind of target-free limbo. ${ }^{8}$

It is the third set of problems related to what the information actually tell us about healthcare providers which Broder and colleagues investigate in their paper from California. ${ }^{1}$ Even in a setting where the amount of investment in information technology can only be dreamed of by those working in most other countries, the published data cover at most only $12 \%$ of procedures. And by looking only at procedures the data ignore the vast amount of care that does not involve one. In other words, such systems capture only a tiny amount of the overall work of a healthcare provider. The information is also largely out of date. Given the rapid pace of change in health care, how useful is it to know, when seeking treatment now, how a provider was doing five years ago?

Although the British public is already ambivalent about the value of such information, ${ }^{9}$ this paper is unlikely to deter those policy makers whose faith in the benefits of publishing the outcomes of healthcare providers is unshakeable by reason, although it may help to inform those who are undecided. In coming to a view they might refer to a sign that Einstein kept on his wall: "Not everything that counts can be counted; not everything that can be counted counts."

Competing interests: None declared.

Broder MS, Payne-Simon L, Brook RH. Measures of surgical quality: what will patients know by 2005? BMJ 2004;328:152-3.

2 Jacobson B, Mindell J, McKee M. Hospital mortality league tables. BMJ 2003;326:777-8.

3 Leyland AH, Boddy FA. League tables and acute myocardial infarction. Lancet 1998;351:555-8.

4 Goldstein H, Spiegelhalter DJ. League tables and their limitations: statistical issues in comparisons of institutional performance. J R Stat Soc A tical issues in compari159:385-443.

5 Marshall EC, Spiegelhalter DJ. Reliability of league tables of in vitro fertilisation clinics: retrospective analysis of live birth rates. BMJ 1998;316:1701-4.

6 Green J, Wintfeld N. Report cards on cardiac surgeons: assessing New York State's approach. N Engl J Med 1995;332:1229-32.

7 Schneider EC, Epstein AM. Influence of cardiac-surgery performance reports on referral practices and access to care: a survey of cardiovascular specialists. N Engl J Med 1996;335:251-6.

8 BBC. Tents prepared for A\&E patients. London: BBC, 2003. http://news.bbc.co.uk/1/hi/health/3235349.stm (accessed 30 Dec 2003).

9 Magee H, Davis L-J, Coulter A. Public views on healthcare performance Magee H, Davis L-J, Coulter A. Public views on healthcare
indicators and patient choice. JR Soc Med 2003;96:338-42.
London School of Hygiene and Tropical Medicine, Tropical WCiE 7HT Martin McKee professor of European public health

martin.mckee@ lshtm.ac.uk 